\title{
ANALISIS PROSES BERPIKIR SISWA SMP DALAM MEMECAHKAN MASALAH ALJABAR DITINJAU DARI GAYA KOGNITIF
}

\author{
Rina Rosdiana*, Novi Andri Nurcahyono, Nur Agustiani \\ Program Studi Pendidikan Matematika, Fakultas Keguruan dan Ilmu Pendidikan, \\ Universitas Muhammadiyah Sukabumi, Sukabumi, Jawa Barat \\ Universitas Muhammadiyah Sukabumi; Jl. R. Syamsudin, SH. No. 50 Kota Sukabumi., Telp. \\ (0266)218345/ Fax. (0266)218342 \\ *e-mail: rose24524@gmail.com
}

\begin{abstract}
Abstrak. Penelitian ini bertujuan untuk dapat menjelaskan proses berpikir siswa yang memiliki gaya kognitif Field Independence dan Field Dependence dalam memecahkan masalah aljabar, sehingga diklasifikasikan dalam penelitian kualitatif. Pengumpulan data dilakukan dengan pemberian Tes Group Embedded Figures Test untuk dapat mengelompokkan gaya kognitif siswa dan menentukan subjek yang kemudian dipilih berdasarkan siswa yang memiliki komunikasi sangat baik, memberikan tes pemecahan masalah aljabar, dan wawancara dengan subjek penelitian setelah menyelesaikan tes pemecahan masalah matematika. Hasil penelitian menunjukkan bahwa siswa yang memiliki gaya kognitif Field Independence dapat dikatakan hampir mampu menyelesaikan soal tersebut dan memenuhi tahapan-tahapan proses berpikir Mason. Pada fase entry mencakup aspek know, want dan introduce, fase attack mencakup aspek try maybe dan why dan pada fase review hanya mencakup aspek check, dan reflect, sedangkan pada subjek kedua hanya mampu mencapai fase entry yang mencakup aspek know, want dan introduce dan fase attack hanya mencakup aspek try saja yang kemudian tidak melakukan fase review. Pada siswa yang memiliki gaya kognitif Field Dependence subjek cenderung hanya mampu mencapai fase entry yang mencakup aspek know, want dan introduce dan fase attack hanya mencakup aspek try saja, sedangkan pada subjek kedua fase entry yang mencakup aspek know dan want kemudian subjek melakukan fase attack hanya pada salah satu soal pemecahan masalah dan selebihnya tidak melakukan fase selanjutnya baik fase attack maupun fase review.
\end{abstract}

Kata kunci: Gaya Kognitif, Proses Berpikir Matematika, Pemecahan Masalah

\begin{abstract}
This study aims to be able to explain the thinking process of students who have cognitive style of Field Independence and Field Dependence in solving algebraic problems, so it is classified in qualitative research. The data collection was done by giving the Embedded Figures Test Group Test to be able to categorize the students' cognitive style and determine the subjects which were then selected based on the students who had excellent communication, gave algebra problem solving test, and interview with the research subject after completing the mathematical problem solving test. The results showed that students who have cognitive style of Field Independence can be said almost able to solve the problem and meet the stages of the process of thinking Mason. In the entry phase includes the aspects of know, want and introduce, the attack phase includes aspects of try maybe and why and in the review phase only covers aspects of check and reflect, while the second subject is only able to reach the entry phase that includes aspects of know, want and introduce and phase attack only includes aspects of the course and then do not do phase review. In students who have a cognitive style of Field Dependence subjects tend to only be able to reach the entry phase that includes aspects of know, want and introduce and the attack phase only includes aspects of the course, while in the second subject entry phase that includes aspects of know and want then the subject to do the attack phase only on one problem-solving problem and the rest do not do next phase either attack phase or review phase.
\end{abstract}

Keywords: Cognitive Style, Mathematical Thinking Process, Problem Solving 


\section{Pendahuluan}

Matematika adalah salah satu mata pelajaran yang diberikan di sekolah pada semua jenjang mulai tingkat dasar sampai perguruan tinggi. Menurut (As'ari, 2016) matematika adalah ilmu universal yang mendasari perkembangan ilmu pengetahuan lainnya seperti ilmu alam, sosial, teknologi dan sebagainya. Pada hakikatnya matematika mampu membekali siswa dengan kemampuan berpikir logis, analitis dan sistematis, sehingga kompetensi ini diberikan agar siswa mampu memecahkan masalah, matematika juga berfungsi untuk pembentukan karakter yang jujur dan disiplin. Matematika sangat penting untuk dipelajari bahkan dikuasai. Literasi penelitian sebelumnya mengenai kesalahan berdasarkan teori newman siswa melakukan kesalahan pada indikator pemahaman soal (Maulana, 2015). Kesalahan-kesalahan tersebut tidak terkecuali pada materi Aljabar. Aljabar adalah salah satu cabang ilmu matematika yang harus dikuasai siswa dalam pembelajaran matematika pada tingkat menengah. Konsep aljabar mulai diperkenalkan semenjak siswa duduk di bangku SMP kelas VII, sehingga ini merupakan masa transisi konsep matematika di SD. Ini yang menjadi alasan aljabar adalah salah satu materi yang susah menurut siswa, terutama dalam pemecahan masalah atau berbentuk soal cerita.

Berdasarkan hasil Ujian Nasional tahun 2014/2015 (Puspendik, 2015) pada indikator menyelesaikan masalah yang berkaitan dengan persamaan linier atau pertidaksamaan linier satu variabel, rata-rata nilai di kota dan kabupaten Sukabumi yaitu 47,84 dan rata-rata nasional yaitu 52,24. Sedangkan pada indikator menentukan pemfaktoran bentuk aljabar ratarata nilai di kota dan kabupaten sukabumi yaitu 60,67 dan rata-rata nasional mencapai 66,55. Keduanya masih tergolong dalam satu rumpun Aljabar namun nilai keduanya berbeda. Hal ini membuktikan bahwa persamaan linier atau pertidaksamaan linier satu variabel adalah salah satu materi yang sulit menurut siswa, terutama dalam pemecahan masalah. Karena perolehan nilai siswa pada indikator tersebut, mendapat nilai yang lebih kecil dibandingkan pemfaktoran bentuk aljabar. Adapun hasil wawancara dengan salah satu guru matematika SMP Negeri 1 Sukaraja pada tanggal 31 desember 2017 menunjukkan bahwa siswa merasa kesulitan pada materi persamaan dan pertidaksamaan linier satu variabel. Banyak faktor yang menyebabkan siswa melakukan kesalahan sehingga menunjukkan rendahnya penguasaan matematika siswa. Faktor tersebut bisa saja berasal dari intern atau ekstern peserta didik, faktor intern diantaranya kecerdasan, motivasi, gaya kognitif, minat, bakat dan lain-lain. Sedangkan pada faktor ekstern dapat dipengaruhi oleh lingkungan keluarga, latar belakang ekonomi, teman dan sebagainya, maka beberapa faktor tersebut dapat berpengaruh dalam memecahkan masalah matematika (Ulya, 2015). Perlu diketahui bahwa setiap individu memiliki karakteristik yang berbeda maka kemampuan siswa dalam memecahkan masalah pun akan berbeda.

Penelitian sebelumnya menunjukkan hasil kemampuan siswa dalam memecahkan masalah matematika berkorelasi positif dengan gaya kognitif yang berdasarkan teori Witkin (Ulya, 2015). Menurut Witkin (Desmita, 2014) gaya kognitif dapat dikelompokkan menjadi beberapa bagian berdasarkan psikologis siswa yang mencerminkan analisis seseorang dalam berinteraksi dengan lingkungannya. Terdapat 2 tipe gaya kognitif yaitu gaya kognitif FI (Field Independence), individu ini cenderung merasa efisien bekerja sendiri, tidak terpengaruh pada kritikan dan mampu menghadapi kesulitan juga dapat mengembangkan struktur, namun kelemahannya perlu bantuan dalam mengingat informasi sosial dan pada 
materi pembelajaran social. Sedangkan gaya kognitif FD (Field Dependence) jika dalam pembelajaran terdapat kritikan maka akan lebih terkecoh, dan sedikit kesulitan menghadapi materi yang terstruktur, namun baik dalam materi sosial dan memiliki ingatan yang lebih baik untuk informasi sosial karena hubungan interaksi sosial yang baik. Gaya kognitif tidak terlepas pada proses berpikir. Menurut Siswono (Yani, 2009) menyatakan bahwa dalam belajar matematika terjadi proses berpikir, proses berpikir adalah upaya aktivitas belajar yang melibatkan proses mental dalam otak agak berpikir secara terarah dan berusaha keluar dari permasalahan yang menantang. Jazuli (Yani, 2009) permasalahan yang mendasar yang dialami oleh kebanyakan siswa adalah rendahnya kualitas peserta didik dalam proses berpikir matematika. Sehingga, informasi proses berpikir siswa dalam menyelesaikan matematika ini akan sangat penting, sebagai upaya memperbaiki kesalahan dengan mengetahui proses berpikir individu maka guru akan dapat mengetahui jenis kesalahan yang dilakukan, juga mengetahui strategi yang tepat untuk dapat memperbaiki kesalahan yang ada (Sudarman, 2009). Oleh karena itu perlunya suatu penelitian mengenai proses berpikir siswa SMP dalam memecahkan masalah aljabar yang ditinjau dari gaya kognitif.

Berdasarkan latar belakang di atas maka dapat dirumuskan pertanyaan-pertanyaan sebagai berikut. Bagaimana proses berpikir siswa dalam memecahkan masalah aljabar yang ditinjau dari gaya kognitif FI (Field Independence)? Bagaimana proses berpikir siswa dalam memecahkan masalah aljabar yang ditinjau dari gaya kognitif FI (Field Independence)?. Berdasarkan rumusan masalah tersebut maka tujuan dari penelitian ini yaitu untuk mengetahui proses berpikir siswa SMP dalam memecahkan masalah aljabar yang ditinjau dari gaya kognitif.

\section{Metode Penelitian}

Penelitian ini merupakan penelitian kualitatif-deskriptif, yang dilaksanakan di SMP Negeri 1 Sukaraja Kabupaten Sukabumi yang berlokasi di jalan siliwangi No 65, Pasirhalang, Sukaraja, Sukabumi. Pengambilan subjek dalam penelitian ini menggunakan teknik Purposive Sampling. Penetapan kategori gaya kognitif, dilakukan berdasarkan hasil tes GEFT. Berdasarkan dari hasil tes GEFT, dipilih 2 orang siswa dari kelompok Field Independence dan 2 orang siswa dari kelompok Field Dependence dengan kriteria diantaranya telah menerima materi persamaan dan pertidaksamaan linier satu variabel, dapat memberikan informasi secara lisan dengan lancar dan, ketersediaan subyek penelitian untuk dapat diteliti. Subjek pada penelitian ini juga merupakan rekomendasi dari guru mata pelajaran matematika mengenai subjek yang memiliki karakter yang kuat mengenai gaya kognitif Field Independence dan Field Dependence.

Instrumen penelitian kualitatif terdiri dari 2 instrumen yaitu: instrumen utama dan instrumen bantu. Instrumen utama adalah peneliti sendiri, sedangkan instrumen bantu yang akan digunakan dalam penelitian ini terdiri dari: 1) Tes Pemecahan Masalah 2) Tes GEFT (Group Embedded Figures Test) 3) Wawancara. Dalam penelitian ini proses analisis dilakukan dengan teknik analisis data yang dikemukakan oleh Miles dan Huberman (Sugiyono, 2015) mengemukakan bahwa aktivitas dalam analisis data kualitatif dilakukan 
secara interaktif dan berlangsung secara terus menerus sampai tuntas, sehingga datanya sudah jenuh. Aktivitas dalam analisis data, yaitu data reduction, data display, dan conclusion drawing/verification. Pengecekkan keabsahan data menggunakan triangulasi teknik Adapun triangulasi yang digunakan pada penelitian ini adalah triangulasi teknik. Triangulasi teknik adalah suatu penggabungan data dan sumber data dengan cara mengumpulkan hasil tes, wawancara dan dokumentasi yang kemudian digabungkan dan dianalisis untuk mendapatkan jawaban yang dapat diambil kesimpulan.

\section{Hasil Penelitian dan Pembahasan}

Berdasarkan hasil analisis data proses berpikir Mason dalam memecahkan masalah aljabar pada materi persamaan dan pertidaksamaan linier satu variabel yaitu: fase entry, yang memiliki 3 aspek diantaranya know, want dan introduce kemudian fase attack memiliki 3 aspek juga yaitu try, maybe dan why lalu fase review juga memiliki 3 aspek yaitu check, reflect dan extend, yang kemudian subjek diambil berdasarkan gaya kognitif menurut Teori Witkin terdapat gaya kognitif FI dan gaya kognitif FD. Diantara seluruh aspek tersebut ratarata subjek hanya mampu memecahkan masalah, dan berhenti pada tahap try saja dan terdapat beberapa persaman dan perbedaan pada setiap tahapan proses berpikir di setiap kategori FI dan FD.

Siswa dengan gaya kognitif FI memiliki salah satu khas atau ciri bahwa yang subjek kerjakan selalu menyelesaikan dengan sistematis. Hal ini selaras dengan teori witkin dalam (Desmita, 2014) yang mengungkapkan bahwa salah satu ciri-ciri karakterisktik gaya kognitif FI adalah memiliki cara berpikir dalam memahami suatu masalah secara analitis dan sistematis. Adapun tahapan proses berpikir siswa dengan Gaya Kognitif FI. Terdapat 2 orang yang menjadi subjek pada penelitian ini satu dari kedua subjek tersebut hampir mencapai seluruh proses berpikir Mason, kecuali pada aspek extend. Kemudian pada subjek lainnya tersebut rata-rata hanya mencapai fase attack pada aspek try, namun cenderung dapat memecahkan masalah melewati ketiga fase tersebut dari mulai aspek know sampai aspek reflect.

Siswa dengan gaya kognitif FD juga memiliki khas pada saat subjek mengerjakan tes pemecahan masalah yaitu subjek kurang menuliskan informasi secara sistematis. Hal ini juga selaras dengan teori witkin dalam (Desmita, 2014)yang mengungkapkan bahwa siswa sedikit merasa kesulitan untuk dapat memfokuskan pada satu aspek, atau menganalisa pola menjadi bagian-bagian yang terpisah. Adapun tahapan proses berpikir siswa dengan Gaya Kognitif FD. Terdapat 2 orang yang menjadi subjek pada penelitian ini satu dari kedua subjek tersebut rata-rata hanya mencapai fase attack pada aspek try. Kemudian pada subjek lainnya tersebut rata-rata hanya mencapai fase entry pada aspek want. Namun cenderung dalam memecahkan masalah pada fase entry hanya menlewati 2 tahap saja yaitu pada aspek know dan want kemudian pada fase attack hanya melakukan aspek try saja. Penelitian ini juga sejalan dengan penelitian Hardianto yang mengungkapkan bahwa subjek FI hampir melakukan semua fase kecuali pada aspek extend, kemudian pada subjek FD hanya sampai aspek try pada fase attack. Berdasarkan hasil dari analisis data yang dilakukan, kemudian diperoleh proses berpikir berdasarkan tahapan Mason dalam memecahkan masalah aljabar pada materi PLSV dan PtLSV sebagai berikut: 


\section{a. Fase Entry}

\section{1) Field Independence}

Pada fase entry terdapat 3 aspek yaitu know, want dan introduce. Untuk kedua subjek FI hampir memenuhi ketiga aspek tersebut dengan baik, karena mampu memahami masalah dengan seksama. Kemudian subjek mampu menuliskan informasi-informasi yang diketahui dan ditanyakan, dan mampu menyusun bahkan memisalkan elemen-elemen yang dapat digunakan untuk dapat menyelesaikan soal dengan baik dan benar juga tidak mengalami kesulitan, hanya 1 yang tidak melakukan aspek inttroduce yaitu S5 pada soal nomor 4, karena tidak dapat menggambarkan kerangka balok. Oleh karena itu pada S5 aspek tersebut dari keempat soal hanya 1 soal yang tidak terselesaikan.

2) Field Dependence

Pada siswa yang memiliki gaya kognitif FD dari ketiga aspek tersebut juga hampir memenuhi ketiga aspek tersebut, hanya saja pada S15 subjek merasa kesulitan pada saat memisalkan elemen yang akan digunakan sehingga aspek ini tidak tercapai, walaupun aspek yang lain terpenuhi siswa yang memiliki gaya kognitif FD selalu memiliki ciri khas dalam menuliskan informasi kurang sistematis dan pada saat menuliskan informasi kurang lengkap, kemudian kurang mampu memisalkan elemen yang dibutuhkan untuk dapat menyelesaikan soal tersebut. Berikut diagram persentase proses berpikir FI dan FD pada fase Entry.

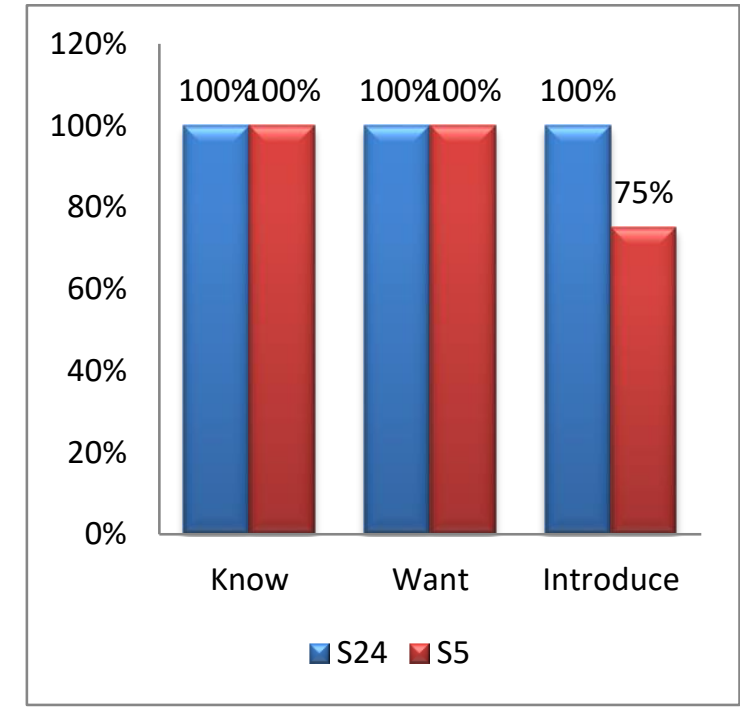

Field Independence

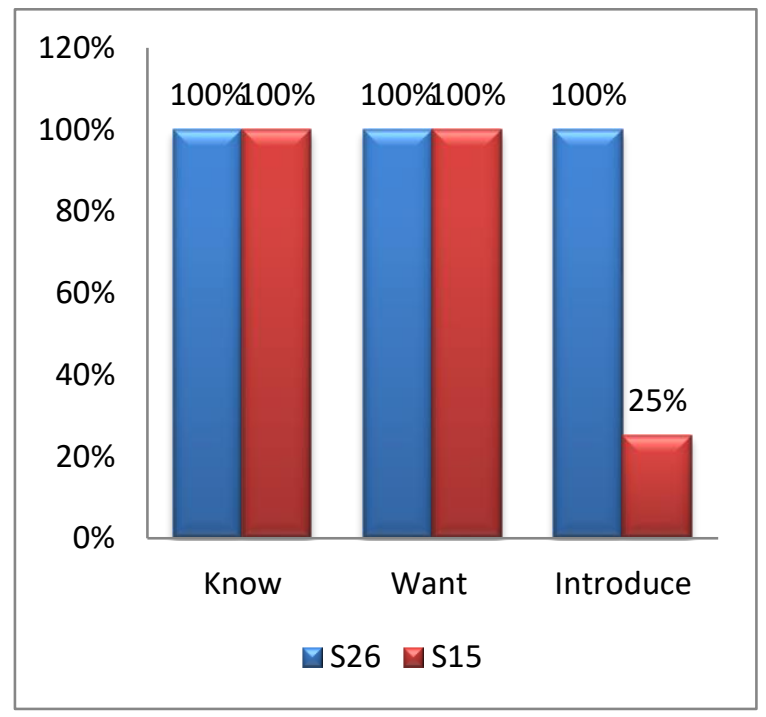

Field Dependence

\section{Gambar 1 Diagram Persentase Proses berpikir FI dan FD Fase Entry}

b. Fase Attack

\section{1) Field Independence}

Pada fase attack terdapat 3 aspek yaitu try, maybe dan why. Untuk siswa yang memiliki gaya kognitif FI hanya memenuhi sebagian dari ketiga aspek yang harus terpenuhi, pada aspek try dengan indikator mampu mengajukan dugaan atau pembuatan perencanaan. S5 tidak memenuhi aspek try pada soal nomor 4, karena pada saat fase entry subjek merasa kesulitan dalam memisalkan elemen yang akan digunakan sehingga ini menjadi suatu hambatan dan 
tidak mampu melanjutkan pada tahap selanjutnya. Adapun aspek maybe dengan indikator mencoba dugaan atau perencanaan dengan benar, S5 juga tidak mampu memenuhi aspek ini pada soal nomor 2, 3 dan 4. Karena pada saat pengerjaan S5 merasa kurang yakin dengan dugaan awal, sehingga pada aspek why juga tidak memenuhi sebab tidak mampu meyakinkan orang lain dengan dugaan atau perencanaan yang digunakan sebelumnya.

\section{2) Field Dependendence}

Pada siswa yang memiliki gaya kognitif FD dari ketiga aspek tersebut juga hanya memenuhi sedikit saja dari seluruhnya. Aspek pertama yaitu try, S15 pada soal nomor 2,3 dan 4 tidak memenuhi aspek try karena subjek tidak mampu melanjutkan kembali, dan hal ini juga berpengaruh pada fase entry. S15 pada saat fase entry hanya memenuhi sampai aspek want saja selebihnya tidak dapat diselesaikan, begitupun aspek kedua maybe dan why S15 tidak memenuhi kedunya. Pada S26 hanya setengahnya saja yang memenuhi aspek try, maybe dan why pada soal nomor 2 dan 3 S26 tidak melakukan aspek maybe dan why. Berikut diagram persentase proses berpikir FD pada fase Attack.

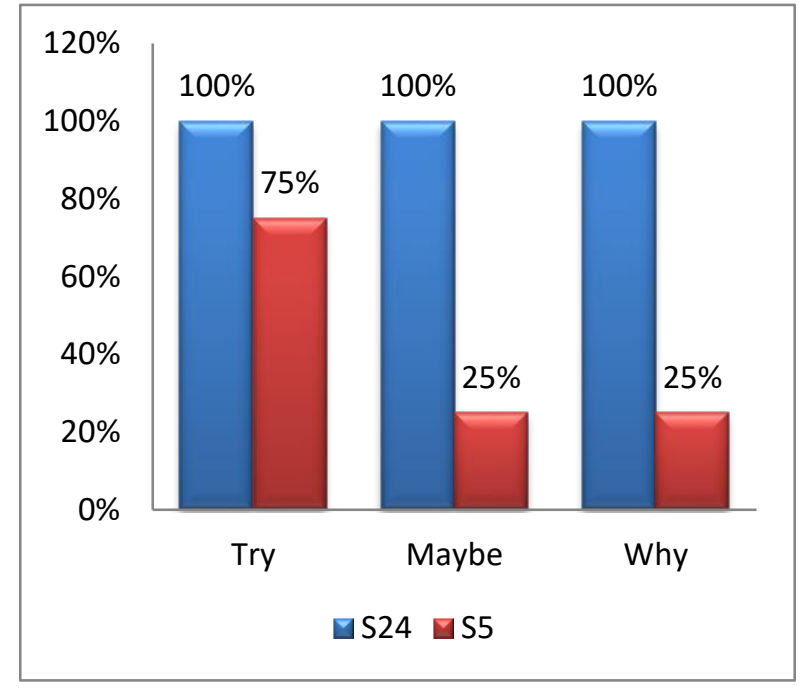

Field Independence

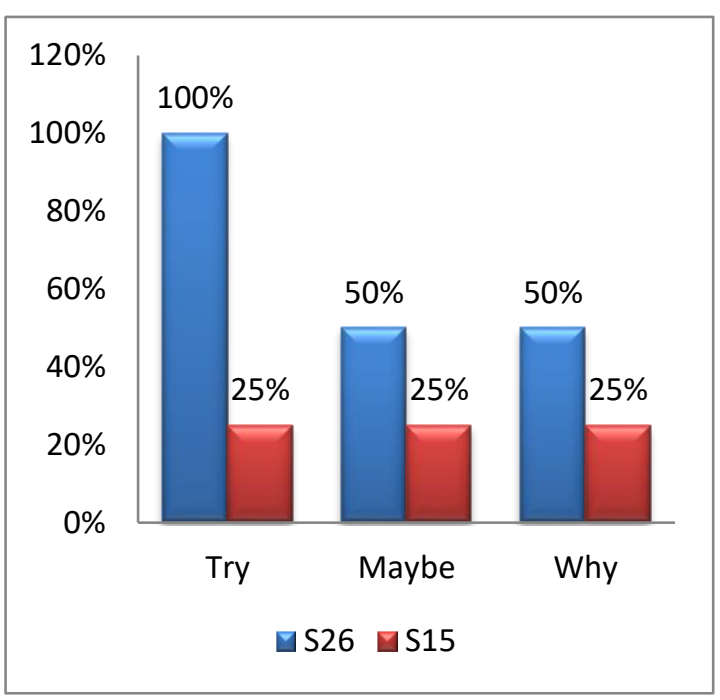

Field Dependence

Gambar 2 Diagram Persentase Proses berpikir FI dan FD Fase Attack

c. Fase Review

1) Field Independence

Pada fase Review juga terdapat 3 aspek yaitu check, reflect dan extend. Pada aspek check dengan indikator mampu mengecek kembali perhitungan dugaan dan kesesuaian langkah penyelesaian dengan pertanyaan. Pada aspek reflect dengan indikator mampu merefleksikan ide penyelesaian bagian mana yang sulit dan merefleksikan dugaan sementara, dan terakhir aspek extend dengan salah satu indikator mampu membuat bentuk umum dari hasil yang diperoleh agar dapat digunakan dalam konteks yang lebih luas. Untuk siswa yang memiliki gaya kognitif FI hanya memenuhi seperempatnya dari ketiga aspek yang harus terpenuhi. S24 tidak memenuhi aspek extend pada keempat soal tersebut, dan S5 tidak memenuhi aspek check, reflect dan extend pada soal nomor 2, 3 dan 4.

2) Field Dependence 
Pada siswa yang memiliki gaya kognitif FD dari ketiga aspek tersebut juga hanya memenuhi sangat sediki yaitu pada S26 dan S15 memenuhi aspek check reflect hanya pada soal no 1 saja, selebihnya subjek tidak melakukan ketiga aspek tersebut. Berikut diagram persentase proses berpikir FI dan FD pada fase Entry.

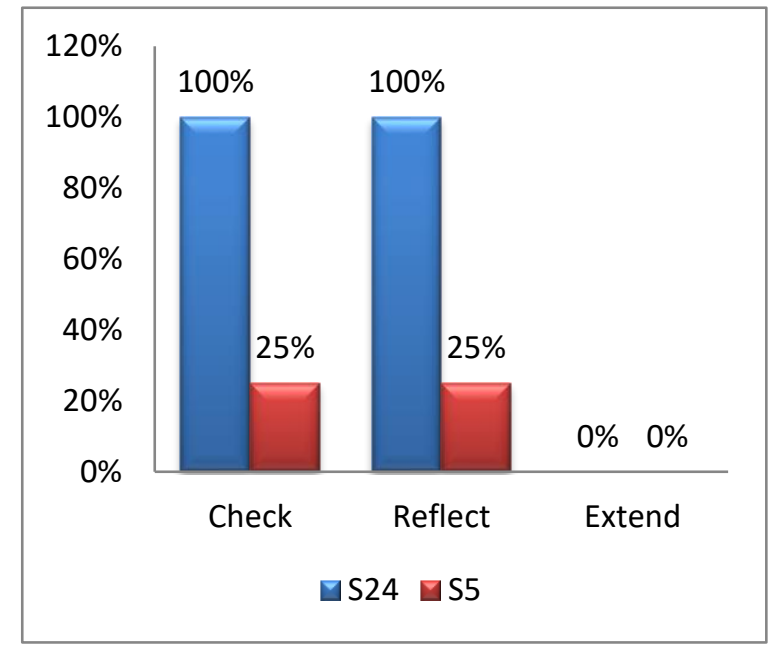

Field Independence

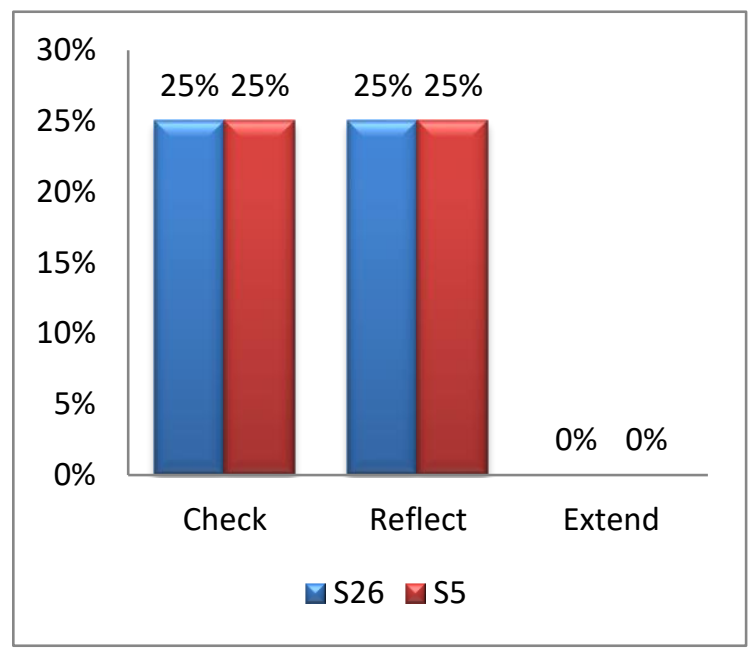

Field Dependence

Gambar 3 Diagram Persentase Proses berpikir FI dan FD Fase Review

Pada siswa yang memiliki gaya kognitif FI diwakilkan oleh S24 dan S5 proses berpikir dengan gaya kognitif FI berdasarkan tahapan proses berpikir Mason pada Fase entry memenuhi ketiga aspek yaitu know, want dan introduce. Kemudian pada Fase attack hampir memenuhi ketiga aspek tersebut. Adapun aspeknya yaitu try, maybe dan why pada aspek tersebut diperlukan kemampuan matematika subjek untuk mampu memecahkan masalah, dikarenakan subjek memiliki kemampuan matematika yang berbeda sehingga pada tahap inilah terjadi perbedaan dan kesamaan. Perbedaannya yaitu pada hasil akhir ketika subjek telah memecahkan masalah. Adapun salah satu kesamaan proses berpikir FI yaitu keduanya menggunakan logika untuk dapat menyelesaikan masalah, dan mampu mempertanggung jawabkan langkah yang telah digunakan. Fase terakhir yaitu review memiliki 3 aspek yaitu check, reflect dan extend pada masing-masing aspek ini diperlukan ketelitian dan ketekunan. Diantara ketiga aspek tersebut rata-rata subjek melakukan aspek check dengan menuliskan kesimpulan dan memeriksa kembali jawaban yang telah ditemukan. Pada fase reflect hanya terjadi jika peneliti berusaha untuk merefleksikan kembali apa yang telah dikerjakan, dan aspek extend dapat dikatakan semua subjek tanpa terkecuali pada siswa yang memiliki gaya kognitif FI belum mampu mencapai pada aspek tersebut.

Pada siswa yang memiliki gaya kognitif FD diwakilkan oleh S26 dan S15 proses berpikir dengan gaya kognitif FD berdasarkan tahapan proses berpikir Mason pada Fase entry memenuhi aspek yaitu know dan want, kecuali pada aspek introduce hal ini kurang terlihat karena berdasarkan hasil menunjukkan bahwa kedua subjek kurang sistematis dan hampir seluruh soal tidak menerjemahkan pernyataan yang seharusnya diterjemahkan terlebih dahulu, sehingga belum memenuhi aspek ini. Kemudian pada Fase attack memiliki aspek yaitu try, 
maybe dan why pada aspek tersebut diperlukan kemampuan matematika subjek untuk mampu memecahkan masalah, dikarenakan subjek memiliki kemampuan matematika yang berbeda sehingga pada tahap inilah terjadi perbedaan dan kesamaan. Perbedaannya yaitu pada hasil akhir ketika subjek telah memecahkan masalah.

Adapun salah satu kesamaan proses berpikir FD yaitu rata-rata kedua subjek tersebut dalam menyelesaikan masalah, hanya dengan beberapa dugaan yang dicoba-coba saja, juga mampu mempertanggung jawabkan langkah yang telah digunakan. Fase terakhir yaitu review memiliki 3 aspek yaitu check, reflect dan extend pada masing-masing aspek ini diperlukan ketelitian dan ketekunan. Diantara ketiga aspek tersebut rata-rata subjek tidak melakukan aspek check dengan menuliskan kesimpulan dan memeriksa kembali jawaban yang telah ditemukan. Pada fase reflect hanya terjadi jika peneliti berusaha untuk merefleksikan kembali apa yang telah dikerjakan, dan aspek extend dapat dikatakan semua subjek tanpa terkecuali pada siswa yang memiliki gaya kognitif FD belum mampu mencapai pada aspek tersebut. Sebagai contoh, adapun salah satu soal dan jawaban siswa FI dan FD dari pengerjaan tes pemecahan masalah aljabar pada materi persamaan linier satu variabel, dapat dilihat pada gambar dibawah ini.

1. Pada tanggal 12 juni 2018 teman ayah Agam menanyakan usia Agam. Agam tidak menyebutkannya secara langsung. Agam menyebutkan bahwa usia ayahnya ketika Agam lahir adalah 26 tahun. Jika dijumlahkan usia Agam dan ayahnya saat ini adalah 50 tahun.

a. Berapakah usia Agam saat ini, dan

b. Berapakah jumlah usia agam dan ayah pada tanggal 13 juni 2023 ?

\section{Gambar 4 Soal pemecahan masalah pada materi PLSV}

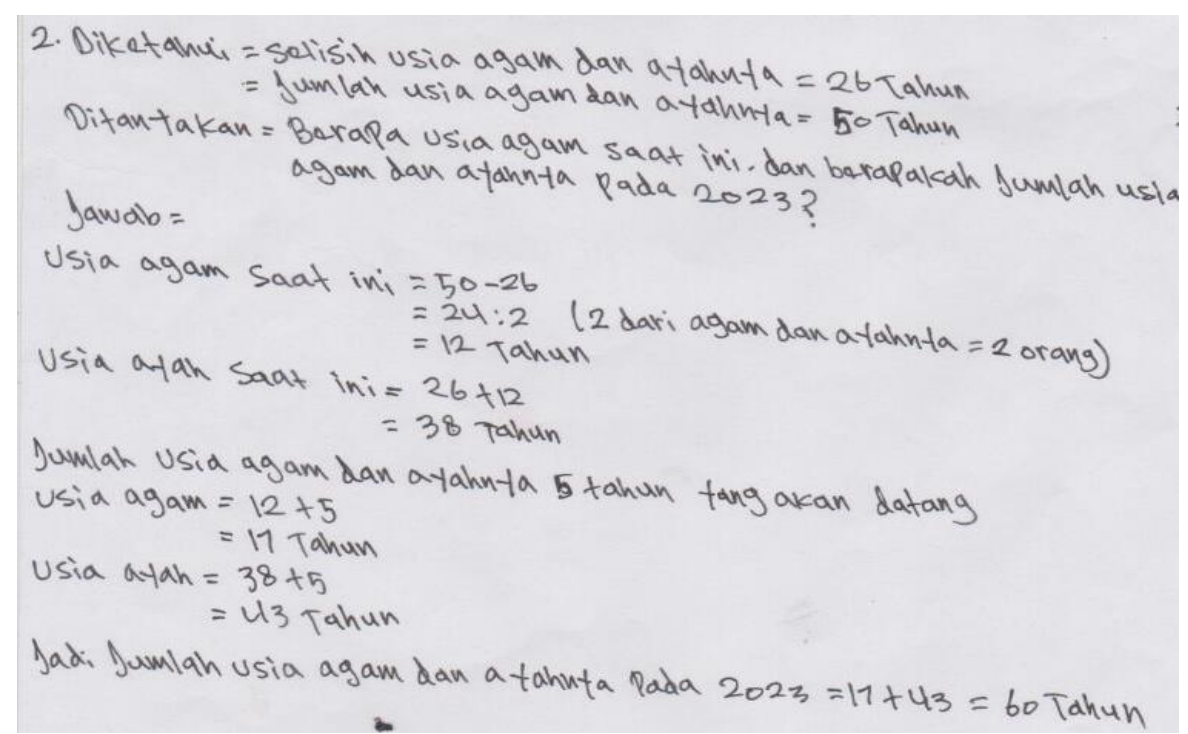

Gambar 5.Hasil Jawaban Subjek FI pada materi PLSV 


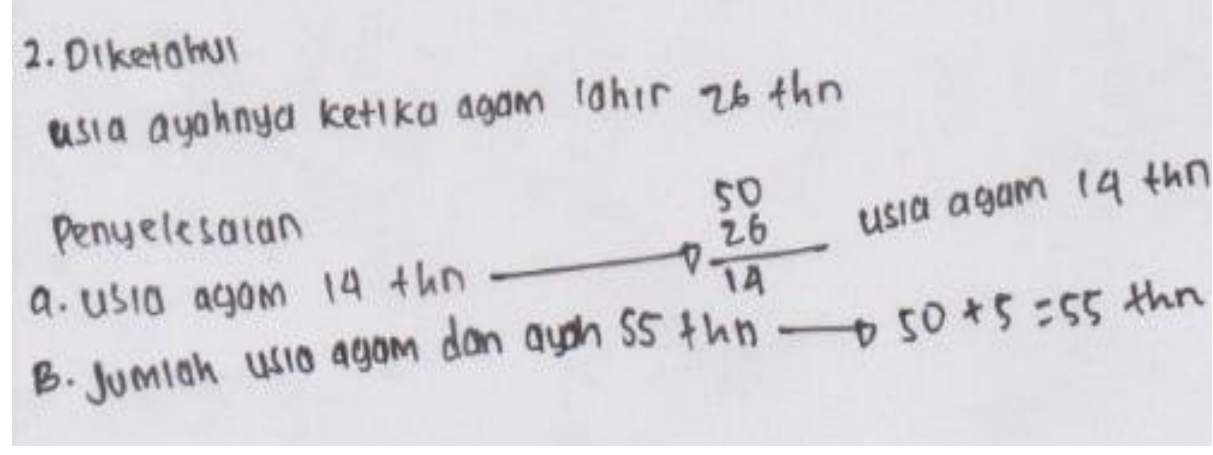

\section{Gambar 6.Hasil Jawaban Subjek FD pada materi PLSV}

Selain pada materi persamaan linier satu variabel, Adapun salah satu jawaban siswa FI dan FD dari pengerjaan tes pemecahan masalah aljabar pada materi pertidaksamaan linier satu variabel, dapat dilihat pada gambar dibawah ini.

1. Pak Roni diberikan beberapa pakaian oleh saudaranya, kemudian Pak Roni membuat suatu ruang penyimpanan yang berbentuk balok, model kerangka balok terbuat dari kawat dengan ukuran panjang $7 \mathrm{~cm}$ lebihnya dari tinggi kerangka tersebut, sedangkan lebar kerangka $3 \mathrm{~cm}$ lebih pendek dari tinggi kerangka. Jika tinggi kerang ka tersebut $x \mathrm{~cm}$. Maka tentukanlah

a. Model matematika dari persamaan panjang kawat yang diperlukan dalam $x$, dan

b. jika panjang kawat yang digunakan seluruhnya tidak lebih dari $196 \mathrm{~cm}$, tentukan ukuran maksimum balok tersebut.?

\section{Gambar 7. Soal pemecahan masalah pada materi PtLSV}

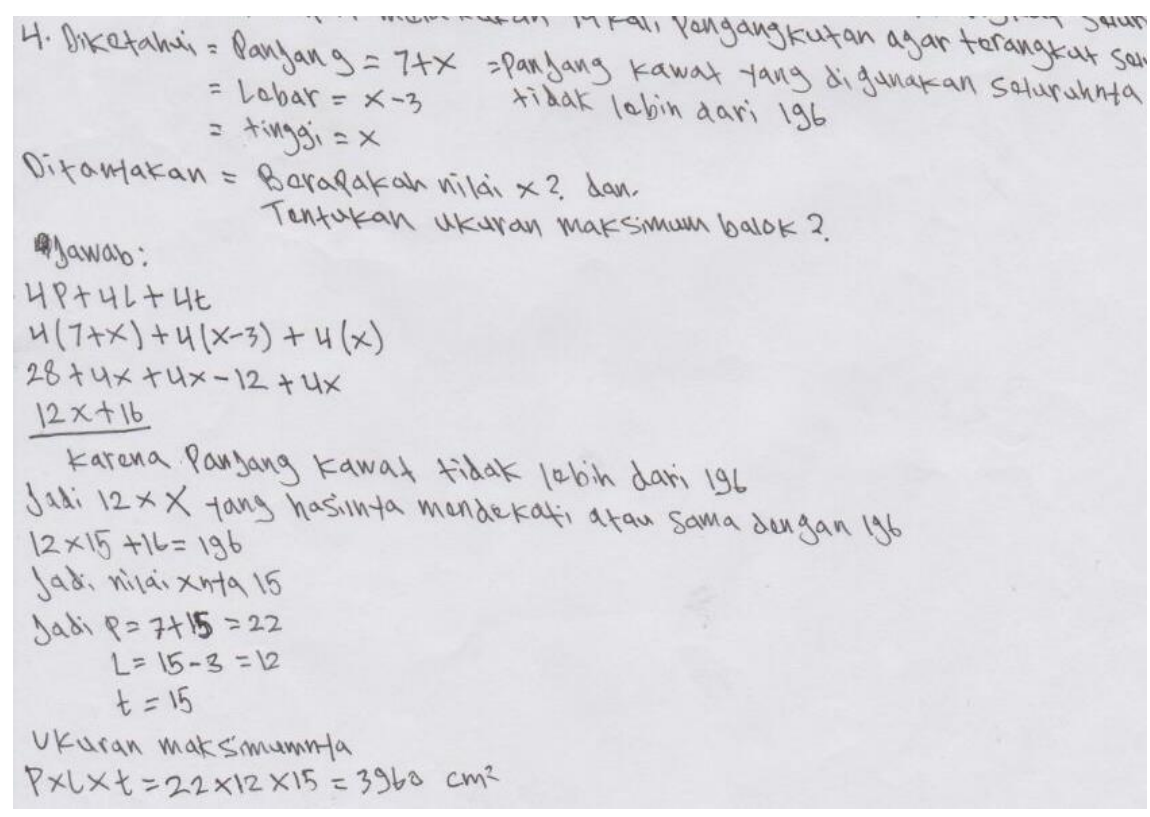

Gambar 8.Hasil Jawaban Subjek FI dan FD pada materi PtLSV 


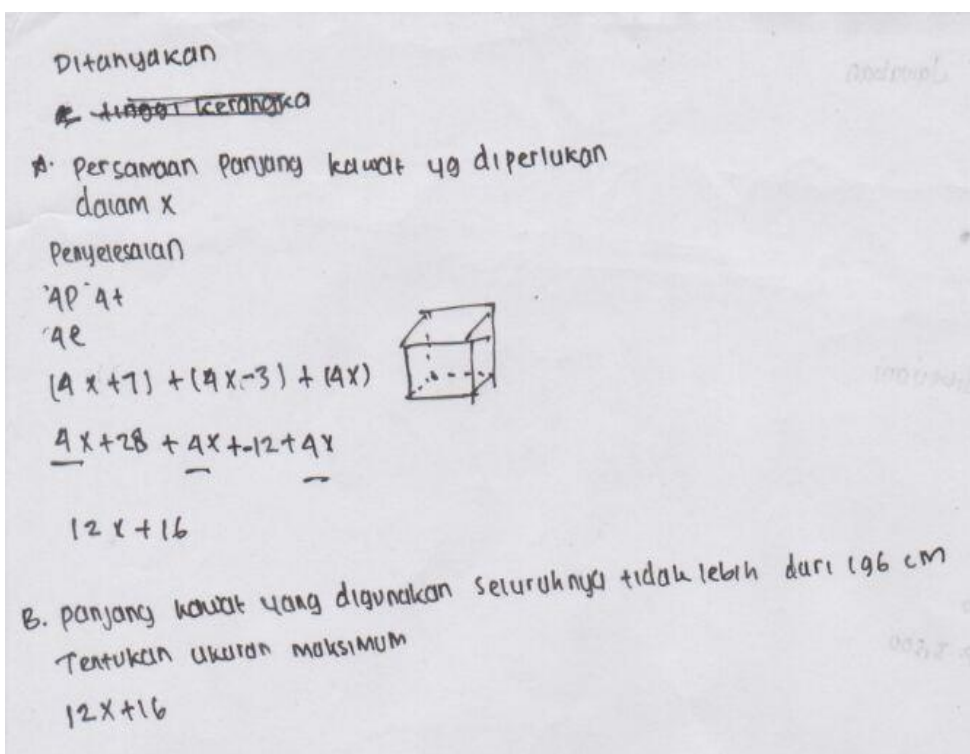

Gambar 9. Hasil Jawaban Subjek FI dan FD pada materi PtLSV

\section{Kesimpulan dan Saran}

Dari hasil penelitian ini ditemukan bahwa proses berpikir siswa yang memiliki gaya kognitif FI dalam memecahkan masalah aljabar memiliki ciri khas tersendiri dalam menyelesaikan masalah. Salah satunya adalah subjek FI dalam memecahkan cenderung lebih analisis dan lebih teliti, namun terdapat perbedaan pada subjek pertama cenderung mampu menyelesaikan dan dapat memecahkan masalah aljabar, jika disusun berdasarkan proses berpikir Mason pada fase entry memenuhi ketiga aspeknya yaitu know, want dan introduce. Fase attack memenuhi aspek try, maybe dan why, kemudian pada fase review hanya memenuhi aspek check dan reflect. Sedangkan pada subjek kedua, pada fase entry hampir memenuhi ketiga aspek tersebut yaitu know, want dan introduce, pada fase attack hanya memenuhi aspek try dan maybe saja, sehingga dapat dikatakan tidak melakukan fase review dan hanya melakukan fase review pada salah satu soal.

Proses berpikir pada siswa yang memiliki gaya kognitif FD dalam memecahkan masalah aljabar cenderung kurang teliti dan sedikit ragu-ragu dalam menyampaikan argumen mengenai langkah yang sudah digunakan. Selain terdapat kesamaan, pada subjek FD juga terdapat perbedaan pada saat memecahkan masalah. Untuk subjek pertama fase entry memenuhi aspek know, want dan introduce, pada fase attack cenderung memenuhi aspek try, maybe dan why dan terkadang hanya sampai aspek try dan maybe saja. Subjek melakukan fase review pada aspek check dan reflect. Sedangkan pada subjek kedua pada fase entry hanya memenuhi aspek know dan want saja, tidak melakukan fase attack dan fase review. Kecuali hanya pada satu soal untuk fase entry memenuhi ketiga aspek yaitu know, want dan introduce pada fase attack memenuhi aspek try, maybe dan why memenuhi seluruh aspek. Pada fase review hanya memenuhi aspek check dan reflect. Sehingga siswa yang memiliki gaya kognitif FI dan FD tidak memiliki perbedaan yang signifikan jika kemampuan keduanya cenderung sama. Berdasarkan hasil penelitian yang diperoleh peneliti menawarkan beberapa saran sebagai berikut:

1) Alangkah baiknya tes GEFT dapat dikembangkan kembali, sehingga tes tersebut dapat digunakan untuk mengetahui gaya kognitif siswa juga mudah untuk didapatkan. 
2) Hendaknya guru memberikan perhatian yang lebih kepada subjek yang memiliki gaya kognitif FD (Field Dependence) dan memiliki kemampuan matematika yang rendah.

3) Mempelajari matematika bukan berada pada hasil akhir namun pada proses berpikir sehingga setidaknya guru memberikan kesadaran kepada siswa untuk dapat memiliki dorongan dan motivasi salah satunya menghargai setiap langkah yang dikerjakan dengan memberikan latihan berupa uraian yang mampu mengungkapkan proses berpikir siswa.

4) Untuk peneliti yang akan melakukan peneliti selanjutnya disarankan untuk dapat memilih subjek penelitian secara lebih luas yaitu siswa dengan gaya kognitif FI yang memiliki kemampuan matematika tinggi dan rendah, dan siswa dengan gaya kognitif FD yang memiliki kemampuan matematika tinggi dan rendah.

5) Alangkah baiknya guru juga memiliki alternatif lain, selain perumpamaan melalui verbal ketika memberikan materi persamaan dan pertidaksamaan linier satu variabel.

\section{Daftar Pustaka}

As'ari, A. R. (2016). Buku Guru Matematika untuk SMP/MtS Kelas VII. Jakarta: Kemdikbud. Desmita. (2014). Psikologi Perkembangan Peserta Didik. Bandung: PT Remaja Rosdakarya.

Maulana, A. S. (2015). Analisis Kesalahan Siswa SMP Azzainiyah Kelas VII dalam Menyelesaikan Soal Transformasi berdasarkan Metode Analisis Kesalahan Newman. Universitas Muhammadiyah Sukabumi.

Puspendik. (2015). Laporan Hasil Ujian Nasional.

Sudarman. (2009). Proses Berpikir Siswa Climber dalam Menyelesaikan Masalah Matematika.

Sugiyono. (2015). Metode Penelitian Kualitatif, Kuantitatif dan R\&D. Bandung: Alfabeta.

Ulya, H. (2015). Hubungan Gaya Kognitif dengan Kemampuan Pemecahan Masalah Matmatika Siswa. Jurnal Konseling GUSJIGANG, 1(2).

Yani, M. (2009). Proses Berpikir Siswa Menengah Pertama dalam Memecahkan Masalah Matematika Berdasarkan Lankah Polya ditinjau dari Adversity Quetiont. Jurnal Pendidikan Matematika, 10(1). 